\title{
Effect of progesterone-carbachol derivative on perfusion pressure and coronary resistance in isolated rat heart: via activation of the $M_{2}$ muscarinic receptor
}

\author{
Lauro Figueroa-Valverde ${ }^{\mathrm{a}}$, Francisco Diaz-Cedillo ${ }^{\mathrm{b}}$, Elodia Garcia-Cervera ${ }^{\mathrm{a}}$, Eduardo Pool Gomez ${ }^{\mathrm{a}}$, Maria Lopez-Ramos ${ }^{\mathrm{a}}$
}

\begin{abstract}
Aim. The present study was designed to investigate the effects of progesterone-carbachol derivative on perfusion pressure and coronary resistance in rats. An additional aim was to identify the molecular mechanisms involved.

Methods. The Langendorff model was used to measure perfusion pressure and coronary resistance changes in isolated rat heart after progesterone-carbachol derivative alone and after the following compounds; mifepristone (progesterone receptor blocker), yohimbine ( $\alpha_{2}$ adreno-receptor antagonist), ICI 118,551 (selective $\beta_{2}$ receptor blocker), atropine (non-selective muscarinic receptor antagonist), methoctramine (antagonist of $M_{2}$ receptor) and L-NAME (inhibitor of nitric oxide synthase).

Results. The results show that progesterone-carbachol derivative $\left[10^{-9} \mathrm{mM}\right]$ significantly decreased perfusion pressure $(P=0.005)$ and coronary resistance $(P=0.006)$ in isolated rat heart. Additionally, the effect of progesterone-carbachol on perfusion pressure $\left[10^{-9}\right.$ to $\left.10^{-4} \mathrm{mM}\right]$ was only blocked in the presence of methoctramine and L-NAME.

Conclusions. These data suggest that progesterone derivative exert its effect on perfusion pressure via activation of the $M_{2}$ muscarinic. In addition, this phenomenon involves stimulation of nitric oxide synthase (NOS).
\end{abstract}

Key words: progesterone-carbachol, langendorff, perfusion pressure, coronary resistance

Received: July 22, 2011; Accepted with revision: January 18, 2012; Available online: January 31, 2012

http://dx.doi.org/10.5507/bp.2012.010

a Laboratory of Pharmaco-Chemistry at the Faculty of Chemical Biological Sciences of the Universidad Autonoma de Campeche, Av. Agustin Melgar s/n, Col Buenavista C.P.24039 Campeche Cam., Mexico

${ }^{b}$ Escuela Nacional de Ciencias Biologicas del Instituto Politecnico Nacional. Prol. Carpio y Plan de Ayala s/n Col. Santo Tomas, Mexico, D.F. C.P. 11340

Corresponding author: Lauro Figueroa-Valverde, e-mail: lauro_1999@yahoo.com

\section{INTRODUCTION}

High blood pressure contributes substantially to cardiovascular disease incidence and premature mortality ${ }^{1-4}$. Studies using the technique of ambulatory blood pressure monitoring have shown that blood pressure is higher in men than in women of similar ages ${ }^{5}$. There are studies which have demonstrated higher incidence of hypertension in women after menopause ${ }^{6}$ which suggests that female sex hormones protect against the development of hypertension. In this sense, there are studies which have shown that oral administration of natural progesterone significantly lowered blood pressure in six men and four postmenopausal women with mild to moderate hypertension who were not receiving antihypertensive drugs ${ }^{7}$. Nevertheless, administration of natural progesterone (200 mg, orally) to seven postclimacteric women failed to influence blood pressure ${ }^{8}$. In addition, another study showed that increases in levels of progesterone were positively correlated with decreases in blood pressure in the progression of pregnancy 9 .

On the other hand, some reports show that administration of a progesterone derivatives also exerts effect on blood pressure; for example, there are reports which indicate that medroxyprogesterone acetate induce changes in blood pressure in postmenopausal women receiving estrogen replacement therapy; this phenomenon, possibly depends the stimulation of sodium retention ${ }^{10}$. However, there are data from clinical studies which provide evidence that sequential administration of medroxyprogesterone acetate or progestogene norethisterone acetate does not alter blood pressure ${ }^{11,12}$. Nevertheless, other studies indicate that another progesterone derivative (drosperidone) causes decreased salt and water retention, and thus lowering of blood pressure through mineral corticoid receptor $^{13}$.

Apart from the above experiments, which also do not show clearly the cellular site and actual molecular mechanisms of progesterone and its derivatives, data are needed for characterizing the activity induced by this steroid at a cardiovascular level. To provide this information, the present study was designed to investigate the effects of progesterone and progesterone-carbachol derivative on perfusion pressure and coronary resistance in isolated rat hearts using the Langendorff model. In addition, the molecular mechanism involved in the activity induced by progesterone-carbachol derivative on perfusion pressure was evaluated using several substances such as mifepristone (progesterone receptor blocker) ( ref. $^{14}$ ), yohimbine ( $\alpha_{2}$ adreno-receptor antagonists) (ref. ${ }^{15}$ ), ICI 118,551 (selective $\beta_{2}$ receptor blocker) (ref. ${ }^{16}$ ), atropine (non-selective muscarinic receptor antagonist) (ref. ${ }^{17}$ ), methoctramine (antagonist of the $\mathrm{M}_{2}$ receptor) (ref. ${ }^{18}$ ) and L-NAME (inhibitor of nitric oxide synthase) (ref. ${ }^{19}$ ) as pharmacological tools. 


\section{MATERIALS AND METHODS}

\section{General methods}

All experimental procedures and protocols used in this investigation were reviewed and approved by the Animal Care and Use Committee of Universidad Autonoma de Campeche (UAC) and were in accordance with the Guide for the Care and Use of Laboratory Animals. Female rats (Wistar; weighing 200-250 g) were obtained from UAC.

\section{Reagents}

Pregnenolone carbachol derivative [2-17-Acetyl-1013-dimethyl-1,2,6,7,8,9, 10,11,12,13, 14,15,16,17-tetradeca hydrocyclopenta[a]phenanthren-3-yl-denecarbamoyloxy)ethyl]-trimethyl-ammonium;chloride (Fig. 1), was synthesized by methods previously reported ${ }^{20}$. All drugs were dissolved in methanol and different dilutions were obtained using Krebs-Henseleit solution $(\leq 0.01 \%$, v/v).

\section{Langendorff method}

Briefly, the male rat (200-250 g) was anesthetized by injecting them with pentobarbital at a dose rate of 50 $\mathrm{mg} / \mathrm{kg}$ body weight. Then the chest was opened, and a loose ligature passed through the ascending aorta. The heart was then rapidly removed and immersed in ice cold physiologic saline solution. The heart was trimmed of non-cardiac tissue and retrograde perfused via a noncirculating perfusion system at a constant flow rate. It is important to mention that the perfusion medium was the Krebs-Henseleit solution $\left(\mathrm{pH} 7.4,37^{\circ} \mathrm{C}\right)$ composed of (mM); $117.8 \mathrm{NaCl} ; 6 \mathrm{KCl} ; 1.75 \mathrm{CaCl}_{2} ; 1.2 \mathrm{NaH}_{2} \mathrm{PO}_{4}$; $1.2 \mathrm{MgSO}_{4} ; 24.2 \mathrm{NaHCO}_{3} ; 5$ glucose, and 5 sodium $p y-$ ruvate. The solution was actively bubbled with a mixture of $\mathrm{O}_{2} / \mathrm{CO}_{2}$ (95:5). The coronary flow was adjusted with

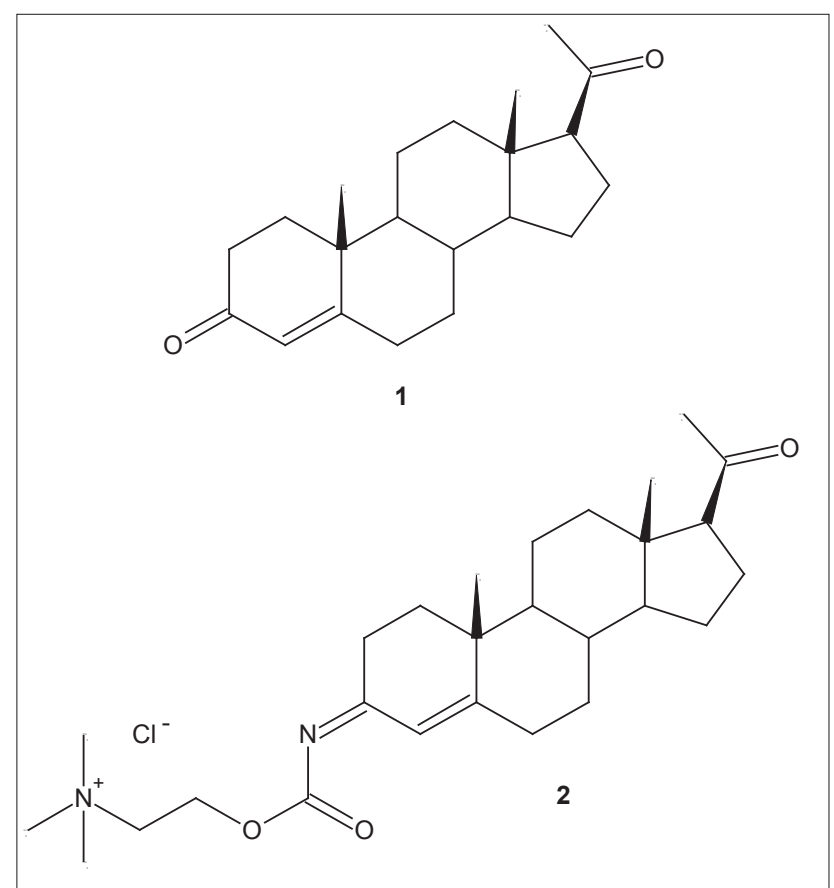

Fig. 1. Structure of progesterone (1) and progesterone-carbachol derivative (2). a variable-speed peristaltic pump. An initial perfusion rate of $15 \mathrm{~mL} / \mathrm{min}$ for $5 \mathrm{~min}$ was followed by a $25 \mathrm{~min}$ equilibration period at a perfusion rate of $10 \mathrm{~mL} / \mathrm{min}$. All experimental measurements were done after this equilibration period.

\section{Perfusion pressure}

Evaluation of measurements of perfusion pressure changes induced by drug application in this study were assessed using a pressure transducer connected to the chamber where the hearts were mounted and the results entered into a computerized data capture system (Biopac).

\section{Biological evaluation \\ First Stage}

Effect of progesterone and progesterone derivative on perfusion pressure. Changes in perfusion pressure over time (3-18 $\mathrm{min}$ ) in the absence (control) or presence of progesterone and the progesterone derivative at a concentration of $1 \times 10^{-9} \mathrm{mM}$ were determined. The effects were obtained in isolated hearts perfused at a constant-flow rate of $10 \mathrm{~mL} / \mathrm{min}$.

Effect of progesterone and progesterone derivative on coronary resistance. The coronary resistance in the absence (control) or presence of progesterone and the progesterone derivative at a concentration of $1 \times 10^{-9} \mathrm{mM}$ was evaluated. The effects were obtained in isolated hearts perfused at a constant flow rate of $10 \mathrm{~mL} / \mathrm{min}$. The coronary resistance was determined by the relationship between coronary flow and perfusion pressure $(\mathrm{mm} \mathrm{Hg} / \mathrm{mL} / \mathrm{min})$.

\section{Second Stage}

Effect of progesterone-carbachol derivative on perfusion pressure in the presence of progesterone-receptor blocker. Boluses $(50 \mu \mathrm{L})$ of progesterone-carbachol [ $10^{-9}$ to $10^{-4}$ $\mathrm{mM}$ ] were administered and the effect on perfusion pressure was evaluated. The bolus was injected at the point of cannulation. The dose-response curve (control) was repeated in the presence of mifepristone at a concentration of $10^{-6} \mathrm{mM}$ (duration of preincubation with mifepristone was by a 10 min equilibration period).

Effect of progesterone-carbachol derivative on perfusion pressure in the presence of $\alpha_{2}$ adrenergic receptor blocker. The boluses $(50 \mu \mathrm{L})$ of progesterone-carbachol $\left[10^{-9}\right.$ to $10^{-4} \mathrm{mM}$ ] were administered and the corresponding effect on the perfusion pressure was evaluated. The bolus was injected at the point of cannulation. The dose-response curve (control) was repeated in the presence of yohimbine at a concentration of $10^{-6} \mathrm{mM}$ (duration of preincubation with yohimbine was by a 10 min equilibration period).

Effects of progesterone-carbachol derivative on perfusion pressure in the presence of $\beta_{2}$ adrenergic receptor blocker. The boluses $(50 \mu \mathrm{L})$ of progesterone-carbachol $\left[10^{-9}\right.$ to $10^{-4} \mathrm{mM}$ ] were administered and the corresponding effect on the perfusion pressure was evaluated. The dose-response curve (control) was repeated in the presence of ICI 118,551 at concentration of $10^{-6} \mathrm{mM}$ (dura- 
tion of preincubation with ICI 118,551 was by a $10 \mathrm{~min}$ equilibration period).

Effect of progesterone-carbachol derivative on perfusion pressure in the presence of non-selective muscarinicreceptor inhibitor. The boluses $(50 \mu \mathrm{L})$ of progesterone derivative $\left[10^{-9}\right.$ to $\left.10^{-4} \mathrm{mM}\right]$ were administered and the corresponding effect on the perfusion pressure was evaluated. The dose-response curve (control) was repeated in the presence of atropine at a concentration of $10^{-6} \mathrm{mM}$ (duration of preincubation with atropine was by a $10 \mathrm{~min}$ equilibration period).

Effects of progesterone-carbachol derivative on perfusion pressure in the presence of $\mathbf{M}_{2}$ muscarinic blocker. The boluses $(50 \mu \mathrm{L})$ of progesterone-carbachol $\left[10^{-9}\right.$ to $10^{-4} \mathrm{mM}$ ] were administered and the corresponding effect on the perfusion pressure was evaluated. The doseresponse curve (control) was repeated in the presence of methoctramine at a concentration of $10^{-6} \mathrm{mM}$ (duration of preincubation with methoctramine was by a $10 \mathrm{~min}$ equilibration period).

Effects of progesterone-carbachol derivative on perfusion pressure in the presence of L-NAME. The boluses $(50 \mu \mathrm{L})$ of progesterone-carbachol $\left[10^{-9}\right.$ to $\left.10^{-4} \mathrm{mM}\right]$ were administered and the corresponding effect on the perfusion pressure was evaluated. The dose-response curve (control) was repeated in the presence of L-NAME at concentration of $10^{-6} \mathrm{mM}$ (duration of preincubation with L-NAME was by a 10 min equilibration period).

\section{Statistical analysis}

The obtained values are expressed as mean \pm SE (standard error), using each heart $(n=9)$ as its own control. The comparation between means was made with a paired Student's t test. In the case of multiple comparisons we used analysis of variance (ANOVA) using the Bonferroni correction factor $^{21}$. The differences were considered significant when $P$ was equal to or smaller than 0.05 .

\section{RESULTS}

Changes in perfusion pressure over time (3-18 min) in the absence (control) or presence of progesterone and progesterone-carbachol derivative were evaluated (Fig. 2). The results showed that progesterone-carbachol $\left[10^{-9} \mathrm{mM}\right]$ significantly decreased the perfusion pressure $(P=0.005)$ in comparison with the control conditions and progesterone. Other results (Fig. 3) indicate that coronary resistance calculated as the ratio of perfusion pressure at the coronary flow assayed $(10 \mathrm{ml} / \mathrm{min})$ was low $(P=0.006)$ in the presence of progesterone-carbachol derivative $\left[10^{-9} \mathrm{mM}\right]$ than in control conditions and progesterone.

The (Fig. 4) shows that progesterone-carbachol derivative, decreased the perfusion pressure in a dose dependent manner $\left[10^{-9}\right.$ to $\left.10^{-4} \mathrm{mM}\right]$ and that this effect was not inhibited by mifepristone $\left[10^{-6} \mathrm{mM}\right]$. In addition, the effect of progesterone-carbachol derivative $\left[10^{-9}\right.$ to $\left.10^{-4} \mathrm{mM}\right]$ on perfusion pressure in the presence of yohimbine (Fig. 5) or ICI 118,551 (Fig. 6) at a concentration of $10^{-6} \mathrm{mM}$ was not inhibited.

Other results shows that the effect of progesteronecarbachol derivative $\left[10^{-9}\right.$ to $\left.10^{-4} \mathrm{mM}\right]$ on perfusion pressure was significantly inhibited $(P=0.005)$ by atropine (Fig. 7) or methoctramine $(P=0.006)$ at a concentration of $10^{-6} \mathrm{mM}$. Finally, the effect of progesterone derivative [ $10^{-9}$ to $10^{-4} \mathrm{mM}$ ] on perfusion pressure was significantly blocked $(P=0.006)$ by L-NAME (Fig. 8$)$ at a concentration of $10^{-6} \mathrm{mM}$.

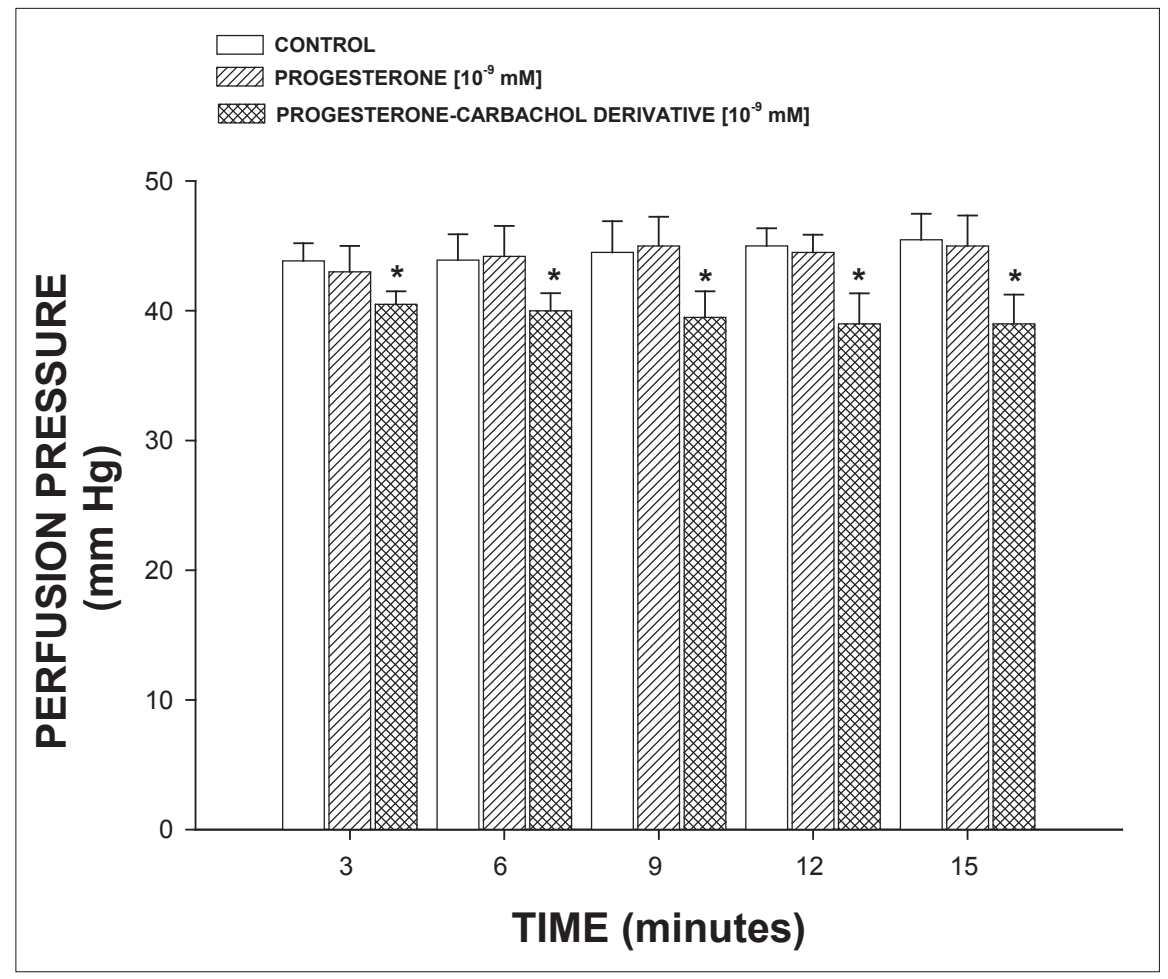

Fig. 2. Effect induced by progesterone and progesterone-carbachol derivative on perfusion pressure. The results showed that progesteronederivative significantly decreased the perfusion pressure $(P=0.005)$ through of time (3-18 $\mathrm{min}$ ) in comparison with the control conditions and progesterone. The effect is expressed as the area under the curve, and each bar represents the mean \pm S.E. of 9 experiments. 


\section{DISCUSSION}

In this study were evaluated the effect of progesterone and progesterone-carbachol derivative on blood vessel capacity and coronary resistance translated as changes in perfusion pressure in isolated rat heart (Langendorff model). The results show that progesterone-carbachol derivative (Fig. 2) significantly decreased the perfusion pressure over time (3-18 $\mathrm{min}$ ) compared to the control conditions and progesterone. These data suggest that progesteronecarbachol derivative exerts effects on perfusion pressure which could subsequently modify vascular tone and coronary resistance. To test this hypothesis, the effects of progesterone-carbachol derivative on coronary resistance were evaluated. We found that coronary resistance was decreased by the progesterone-carbachol derivative (Fig. 3 ). These data suggest that progesterone-carbachol derivative exerts effect on vascular tone. To characterize the molecular mechanism of this phenomenon we analyzed the reports of some investigations which indicate that progesterone induces its effect on blood pressure via activation of the progesterone receptor ${ }^{22,23}$. For this reason, we used mifepristone, a progesterone receptor blocker ${ }^{14}$ to determine if the effects of progesterone-carbachol derivative on perfusion pressure were via the progesterone receptor. It is important to mention that interaction of progesterone-carbachol derivative with the progesterone -receptor may be a key requirement for the biological activ-
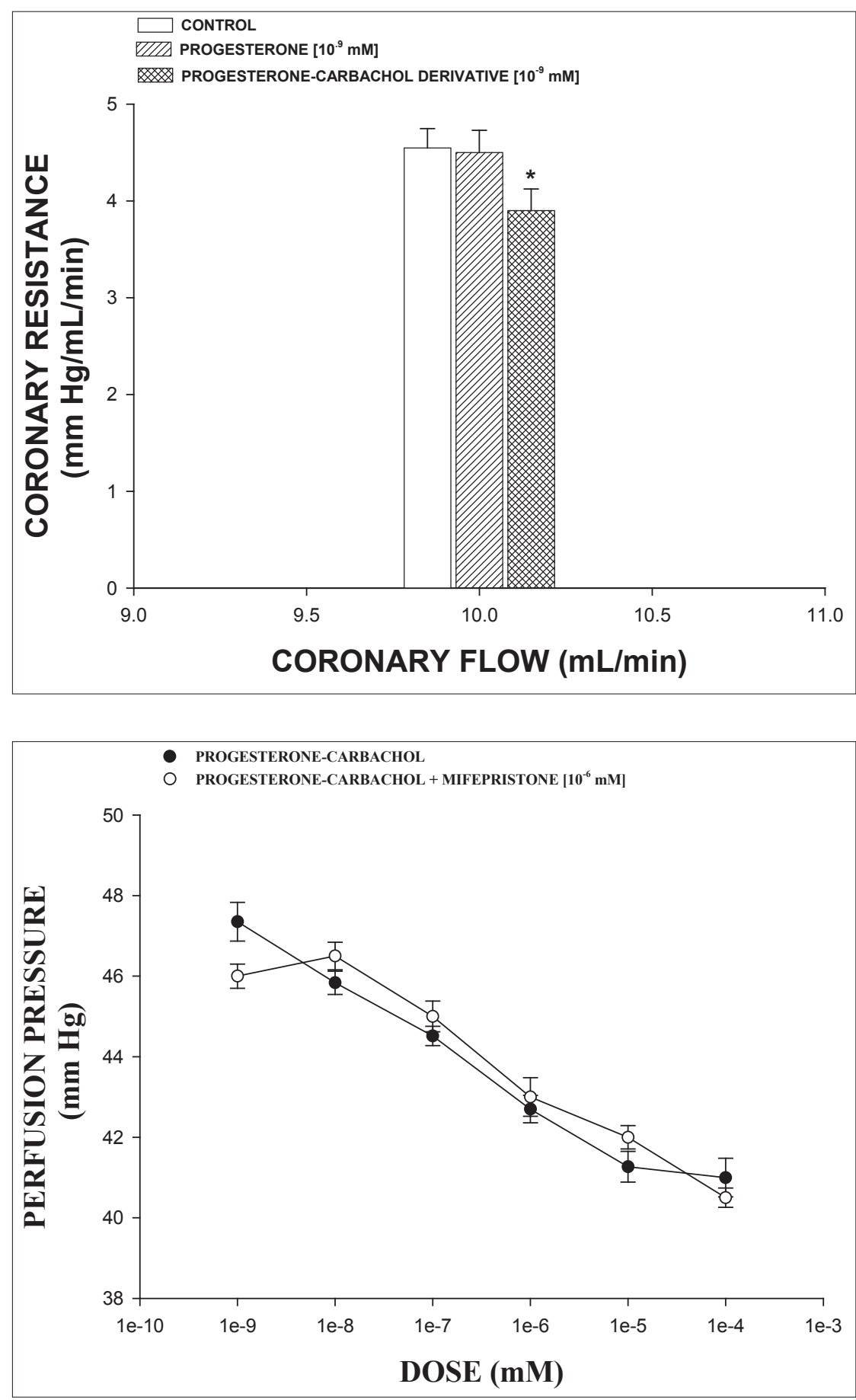

Fig. 3. Activity induced by progesterone and progesterone-carbachol derivative on coronary resistance. The results showed that coronary resistance was lower in presence of progesterone-carbachol $(P=0.006)$ in comparison with the control conditions and progesterone. The effect it is expressed as the area under the curve, and each bar represents the mean \pm S.E. of 9 experiments.

Fig. 4. Effects induced by progesterone-carbachol derivative on perfusion pressure through progesterone-receptor. Intracoronary boluses $(50 \mu \mathrm{L})$ of progesterone-carbachol $\left(10^{-9}\right.$ to $\left.10^{-4} \mathrm{mM}\right)$ were administered and the corresponding effect on the perfusion pressure was determined. The results showed that progesterone derivative decreased the perfusion pressure in a dependent dose manner and this effect was not inhibited in presence of mifepristone $\left(10^{-6} \mathrm{mM}\right)$. The effect it is expressed as the area under the curve, and each bar represents the mean \pm S.E. of 9 experiments. 
ity as in the case of other progesterone derivatives ${ }^{24}$. Our results showed that the effects of progesterone-carbachol derivative were not inhibited by mifepristone (Fig. 4), suggesting that the molecular mechanism is not via the progesterone receptor.

Analyzing these results and other reports which indicate that progesterone can regulate adrenal catecholamine synthesis ${ }^{25-27}$, which has an important role in the development or maintenance of elevated blood pressure ${ }^{28}$. Therefore, in this study the biological activity of progesterone-carbachol derivative on perfusion pressure in the absence or presence of yohimbine (Fig. 5) or ICI 118,551 (Fig. 6) was evaluated. Our results showed that the effect of progesterone derivative was not inhibited by yohimbine or ICI 118,551, indicating that the molecular mechanism involved is not through adrenergic activity.

Analyzing these results and other reports which indicate that carbachol induces activation of $\mathrm{M}_{2}$ muscarinic which induces consequently a negative inotropic response and low blood pressure by activation of nitric oxide synthase (NOS) and increased production of cyclic GMP $\left(\right.$ ref. $\left.^{29}\right)$. In this study the activity of progesterone-carbachol derivative on perfusion pressure was evaluated in the absence or presence of atropine (Fig. 7). The results showed that effect of progesterone-derivative on perfusion pressure was inhibited in the presence of atropine. These results indicate that the effect of the progesterone derivative is via activation of the muscarinic receptor. Therefore,
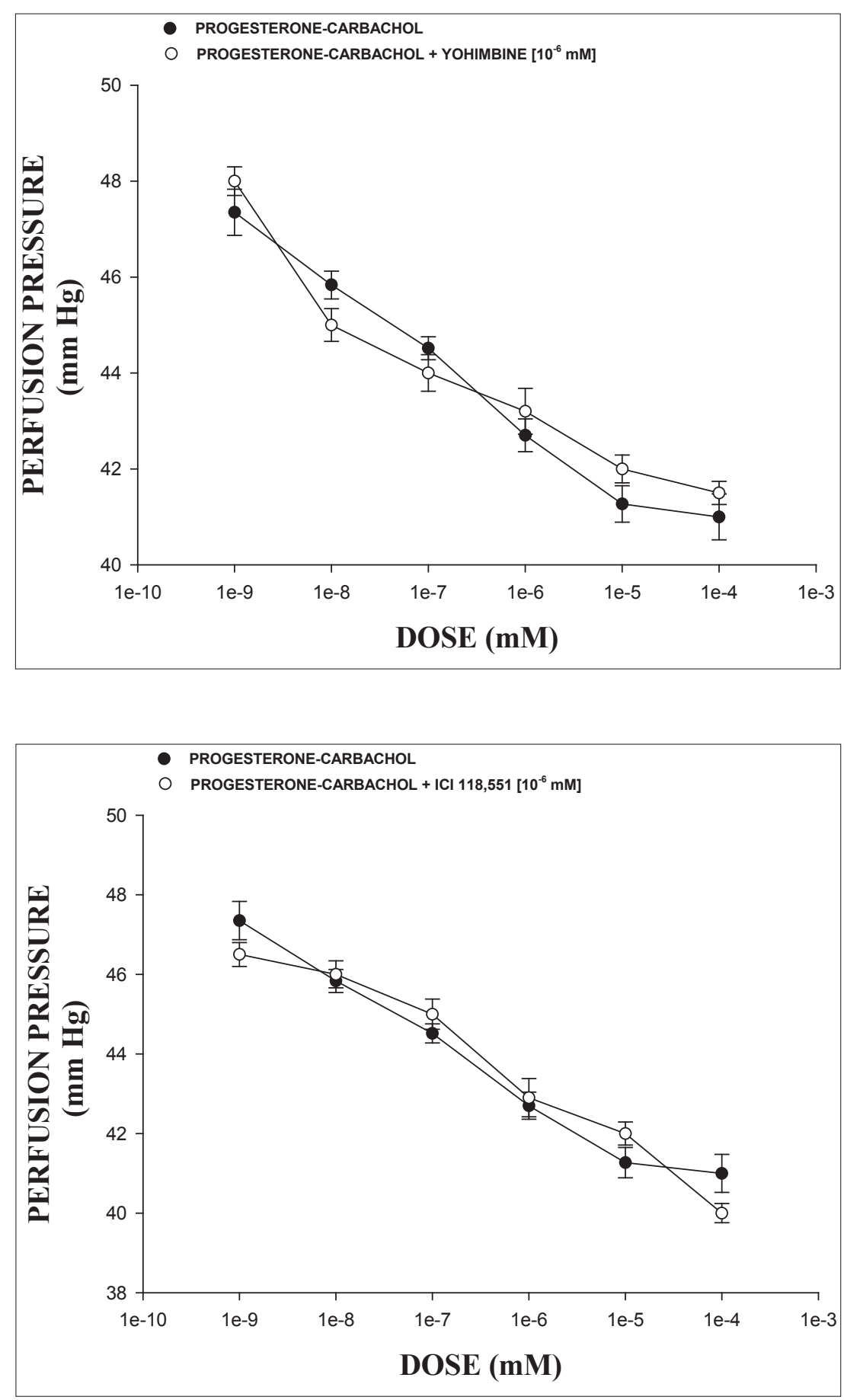

Fig. 5. Effect exerted by progesteronecarbachol derivative on perfusion pressure through of $\alpha_{2}$-adrenergic receptor. progesterone-carbachol $\left(10^{-9}\right.$ to $\left.10^{-4} \mathrm{mM}\right)$ was administered (intracoronary boluses, $50 \mu \mathrm{L}$ ) and the corresponding effect on the perfusion pressure was evaluated in absence and presence of yohimbine $\left(10^{-6}\right.$ $\mathrm{mM})$. The results showed that activity induced by progesterone-derivative on perfusion pressure was not inhibited in presence of yohimbine. The effect it is expressed as the area under the curve, and each bar represents the mean \pm S.E. of 9 experiments.

Fig. 6. Activity induced by progesteronecarbachol derivative on perfusion pressure through of $\beta_{2}$-adrenergic receptor. Intracoronary boluses $(50 \mu \mathrm{L})$ of progesterone- derivative $\left(10^{-9}\right.$ to $\left.10^{-4} \mathrm{mM}\right)$ were administered and the corresponding effect on the perfusion pressure was evaluated in absence and presence of ICI 118,551 $\left(10^{-6} \mathrm{mM}\right)$. The results showed that activity induced by progesterone-derivative on perfusion pressure was not inhibited in presence of ICI 118,551. The effects it is expressed as the area under the curve, and each bar represents the mean \pm S.E. of 9 experiments. 
analyzing these experimental data, we also considered validating the effect of progesterone-carbachol derivative on perfusion pressure via the $\mathrm{M}_{2}$ receptor. In this sense, in this study we evaluated the effect of progesteronederivative in the absence or presence of methoctramine (Fig. 7). The results showed that the activity of progesterone derivative on perfusion pressure in the presence of methoctramine was blocked significantly. The results indicate that the activity of steroid-derivate on perfusion pressure involved indirect stimulation of the $\mathrm{M}_{2}$ receptor. To evaluate which vasoactive substance could also be involved in the changes induced by progesterone-derivative on blood pressure, we also validated the effect of the progesterone-carbachol derivative on perfusion pressure via nitric oxide. The effect of progesterone-derivative in the absence or presence of L-NAME (Fig. 8) was evaluated. The results show that the effect of progesterone derivative on perfusion pressure was blocked in the presence of L-NAME. The data show that effect induced by progesterone-carbachol derivative on perfusion pressure is through activation of nitric oxide synthase and increased production of nitric oxide. This hypothesis is similar to explanations for the effect of some steroid derivatives on perfusion pressure involving increase in nitric oxide by stimulation of nitric oxide synthase ${ }^{30}$.
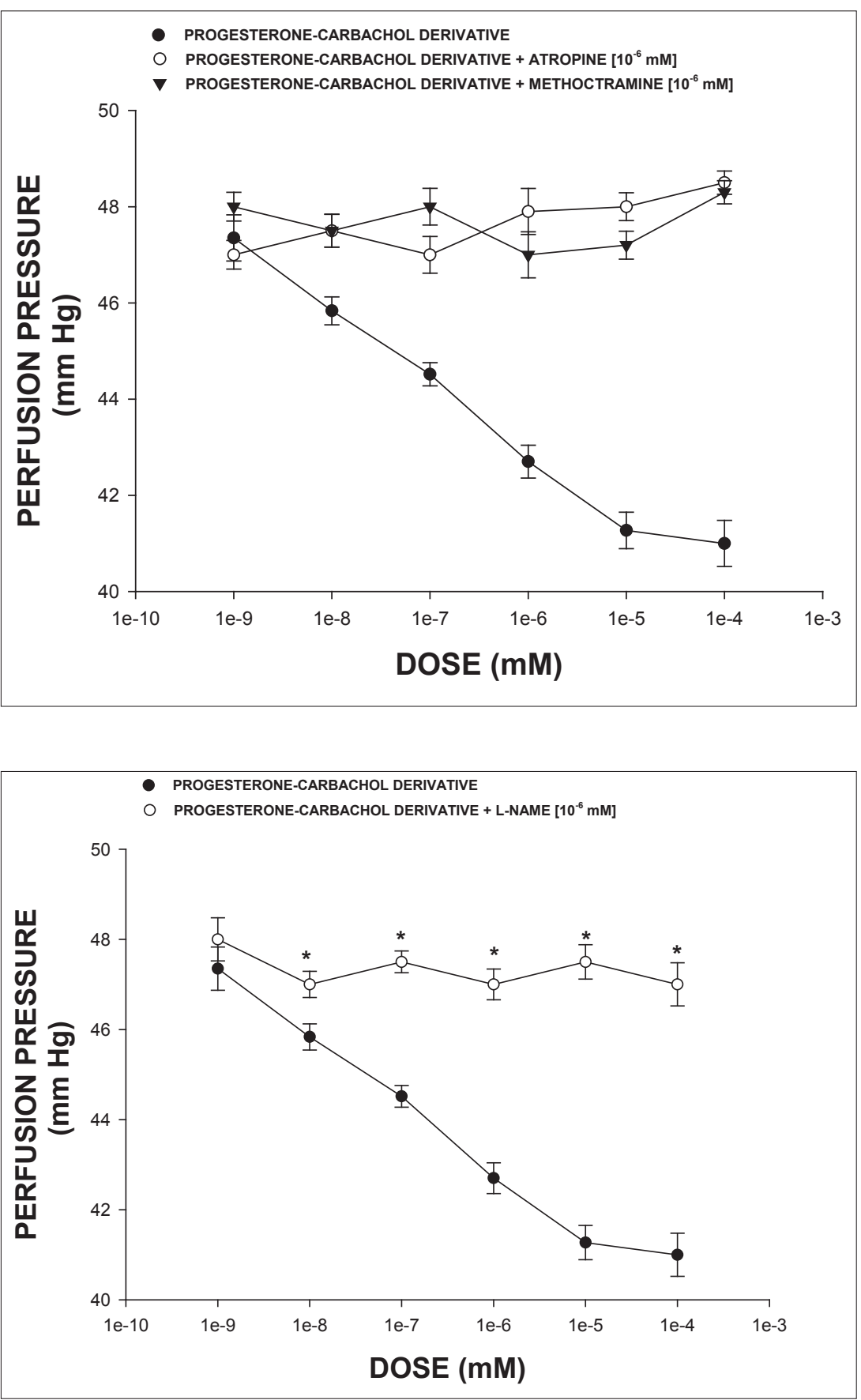

Fig. 7. Effects induced by progesteronecarbachol derivative on perfusion pressure through of muscarinic receptors. Intracoronary boluses $(50 \mu \mathrm{L})$ of progesterone-derivative $\left[10^{-9}\right.$ to $10^{-4} \mathrm{mM}$ ] were administered in absence and presence of atropine or methoctramine $\left(10^{-6} \mathrm{mM}\right)$. The results showed that effect induced by progesterone-carbachol derivative on perfusion pressure in presence of atropine or methoctramine was inhibited. The effect it is expressed as the area under the curve, and each bar represents the mean $\pm \mathrm{SE}$ of 9 experiments.

Fig. 8. Effects exerted by progesteronecarbachol derivative on perfusion pressure through of synthesis of nitric oxide. Progesterone-derivative $\left(10^{-9}\right.$ to $\left.10^{-4} \mathrm{mM}\right)$ was administered (intracoronary boluses, $50 \mu \mathrm{L}$ ) and the corresponding effect on the perfusion pressure was evaluated in absence and presence and L-NAME (10$\left.{ }^{6} \mathrm{mM}\right)$. The results showed that activity induced by progesterone-carbachol derivative on perfusion pressure in presence of L-NAME was inhibited significantly $(P=0.006)$. The effect it is expressed as the area under the curve, and each bar represents the mean \pm S.E. of 9 experiments. 


\section{CONCLUSIONS}

The experimental data obtained in this study suggest that progesterone derivative exerts its effect on perfusion pressure via activation of the $\mathbf{M}_{2}$ muscarinic receptor. This phenomenon also involves stimulation of nitric oxide synthase (NOS).

\section{REFERENCES}

1. Stary HC. Evolution and progression of atherosclerotic lesions in coronary arteries of children and young adults. Arterioscler 1989;9:119 32.

2. Mahoney L, Burns T, Stanford W. Coronary risk factors measured in childhood and young adult life are associated with coronary artery calcification in young adults. J Am Coll Cardiol 1996;27:277-84.

3. Oparil S, Zaman A, Calhoun A. Phatogenesis of hypertension. Ann Intern Med 2003; 139:761-76.

4. Khoury S, Yarows SA, O'brien TK, Sowers JR. Ambulatory blood pressure monitoring in a nonacademic setting: Effects of age and sex. Am J Hypertens 1992;5:616-23.

5. Wiinberg N, Hoegholm A, Christensen HR, Bang LE, Mikkelsen KL, Nielsen P, Svendsen T, Kampmann J, Madsen N, Bentzon MW. 24-h Ambulatory blood pressure in 352 normal Danish subjects, related to age and gender. Am J Hypertens 1995;8:978-86.

6. Staessen J, Bulpitt CJ, Fagard R, Lijnen P, Amery A. The influence of menopause on blood pressure. J Hum Hypertens 1989;3:427-33.

7. Rylance P B, Brincat M, Lafferty K, De Trafford J C, Brincat S, Parsons $\mathrm{V}$, Studd J W. Natural progesterone and antihypertensive action. $\mathrm{Br}$ Med J 1985;5:13-4

8. Tapanainem J, Kauppila A, Metsa-Ketela T, Vapatalo H. Prostanoids and catecholamines after oral administration of natural progesterone. Gynecol Endocrinol 1989;3:135-42.

9. Kristiansson P, Wang JX. Reproductive hormones and blood pressure during pregnancy. Hum Reprod 2001;16:13-7.

10. Oelkers W, Schoneshofer M, Blumel A. Effects of progesterone and four synthetic progestagens on sodium balance and the renin-aldosterone system in man. J Clin Endocrinol Metab 1974;39:882-90.

11. Rosano G, Webb C, Chierchia S, Morgani G, Gabraele M, Sarrel P, De Ziegler D, Collins P, Natural progesterone, but not medroxyprogesterone acetate, enhances the beneficial effect of estrogen on exercise-induced myocardial ischemia in postmenopausal women. J Am Coll Cardiol 2000;36:2154-9.

12. Wilson ES, Cruckshank J, McMaster M, Weir RJ. A prospective controlled study of the effect on blood pressure of contraceptive preparations containing different types and dosages of progestogen. $\mathrm{Br}$ Obstet Gynaecol 1984;91:1254-60.

13. Sitruk-Ware R. Pharmacology of different progestogens: the specia case of drospirenone. Climacteric 2005;8(3):4-12.

14. Couzinet B, Le Strat N, Ulmann A, Baulieu E, Schaison G. Termination of Early Pregnancy by the Progesterone Antagonist RU 486 (Mifepristone). N Engl J Med 1986; 315:1565-70.

15. Bruck H, Gössl M, Spitthöver R, Schäfers R, Kohnle M, Philipp T, Wenzel R. The nitric oxide synthase inhibitor L-NMMA potentiates noradrenaline-induced vasoconstriction: effects of the alpha2-receptor antagonist yohimbine. J Hypertens 2001:19;907-11.

16. Bilski AJ, Halliday SE, Fitzgerald JD, Wale JL. The Pharmacology of a [beta]2-Selective Adrenoceptor Antagonist (ICI 118,551). J Cardiovasc Pharmacol 1983;5:430-7.

17. Wall SJ, Yasuda RP, Li M, Ciesla W, Wolfe BB. Differential regulation of subtypes M1-M5 of muscarinic receptors in forebrain by chronic atropine administration. J Pharmacol Exp Ther 1992;262:584-8.

18. Watson N, Barnes P, Maclagan J. Actions of methoctramine, a muscarinic $\mathrm{M} 2$ receptor antagonist, on muscarinic and nicotinic cholinoceptors in guinea-pig airways in vivo and in vitro. Br J Pharmacol 1992;105:107-12.

19. Moore $P$, Babbedge R, Wallace $P$, Gaffen Z, Hart S. L-Nitro indazole, an inhibitor of nitric oxide synthase, exhibits anti-nociceptive activity in the mouse without increasing blood pressure. Br J Pharmacol 1993;108:296-7.

20. Fiqueroa-Valverde L, Díaz-Cedillo F, López-Ramos M, García-Cervera E, Pool-Hernandez E. Asian J Chem 2012;24. In press.

21. Hocht C, Opezzo J, Gorzalczany S, Bramuglia G, Tiara C. Una aproximación cinética y dinámica de metildopa en ratas con coartación aórtica mediante microdiálisis. Rev Arg Cardiol 1999;67:769-73.

22. D A Bayliss, D E Millhorn, E A Gallman, and J A Cidlowski. Progesterone stimulates respiration through a central nervous system steroid receptor-mediated mechanism in cat. Proc Nat Acad Sci 1987;84:7788-92

23. Williams S, Sigler P. Atomic structure of progesterone complexed with its receptor. Nature 1998;393:392-6.

24. Melcangi R, Magnaghi V, Cavarretta I, Zucchi I, Bovolin P, D'Urso D, Martini L. Progesterone derivatives are able to influence peripheral myelin protein 22 and $P$ gene expression: Possible mechanisms of action. J Neurosc Res 1999;56:349-57.

25. Vivat V, Cohen-Tannoudji J, Revelli J, Muzzin P, Giacobino J, Maltier J, Legrand $C$. Progesterone transcriptionally regulates the beta 2-adrenergic receptor gene in pregnant rat myometrium. J Biol Chem 1992;267:7975-8.

26. Jacobson L, Riemer R, Goldfien A, Lykins D, Siiteri P, Roberts J. Rabbit myometrial oxytocin and $a_{2}$-adrenergic receptors are increased by estrogen but are differentially regulated by progesterone. Endocrinol 1987;120:1184-9.

27 Thawornkaiwong A, Preawnim S, Wattanapermpool J. Upregulation of $\beta$-adrenergic receptors in ovariectomized rat hearts. Life Sci 2003;72:1813-24.

28 Lilley J, Golden J, Stone R. Adrenergic regulation of blood pressure in chronic renal failure. J Clin Invest 1976;57:1190-200.

29. Sterin-Borda L, Echagüe A, Leiros C, Genaro A, Borda E. Endogenous nitric oxide signalling system and the cardiac muscarinic acetylcholine receptor-inotropic response. Br J Pharmacol 1995;115:1525-31.

30. Darblade B, Pendaries C, Krust A, Dupont S, Estradiol Alters Nitric Oxide Production in the Mouse Aorta Through the a-, but not $\beta$-, Estrogen Receptor. Circ Res 2002;90:413-19. 